
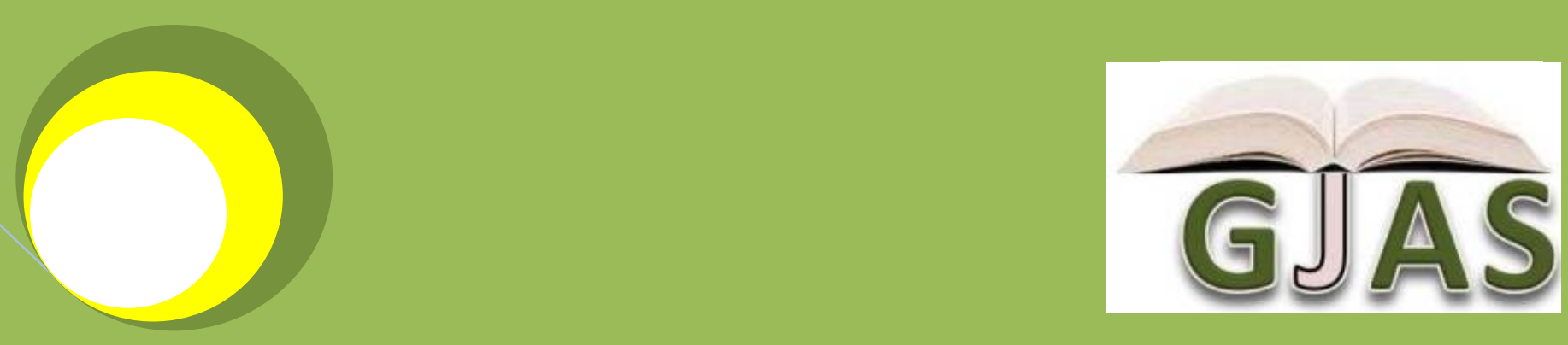

Greener.Journal of Agricultural Sciences

ISSN: 2276-7770 ICV: 6.15

Submission Date: 11/07/2015

Accepted: 18/07/2015

Published: 21/09/2015

Subject Area of Article: Mycology/Mushroom Production

DOI: http://doi.org/10.15580/GJAS.2015.5.071115091

Comparative Studies

on Growth and Yield

of Oil Palm Mushroom,

Volvariella Volvacea

(Bull. Ex. Fr.) Sing. on

Different Substrates

By

Apetorgbor, A. K.

Apetorgbor, M. M.

Derkyi, N. S. A.

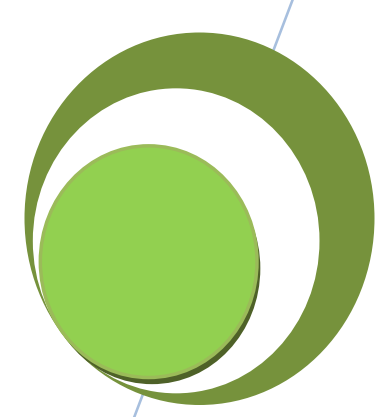




\title{
Comparative Studies on Growth and Yield of Oil Palm Mushroom, Volvariella Volvacea (Bull. Ex. Fr.) Sing. on Different Substrates
}

\author{
*1 Apetorgbor, A.K., ${ }^{2}$ Apetorgbor, M.M., ${ }^{3}$ Derkyi, N.S.A. \\ ${ }^{1}$ Department of Theoretical and Applied Biology, KNUST, Kumasi, Ghana \\ ${ }^{2}$ Forestry Research Institute of Ghana, P. O. Box 63, KNUST, Kumasi, Ghana \\ ${ }^{3}$ University of Energy and Natural Resources, Sunyani, Ghana \\ *Corresponding Author’s Email: alfredapetorgbor@ yahoo.com
}

\begin{abstract}
Edible mushrooms are collected in the countryside and forest regions for consumption and some sold for income. They are highly nutritional and medicinal. The oil palm mushroom, Volvariella volvacea (Bull. Ex. Fr.) Sing., a highly priced and preferred edible mushroom is cultivated using traditional methods which result in low and inconsistent yields. This study was conducted to compare the performance of various local substrates and supplements on the yield of $V$. volvacea using the low and high bed cultivation methods.

Various agricultural wastes among others were used in preparing low and high beds sprinkled with grain spawn of $V$. volovacea. The beds were covered with thick transparent polyethylene sheets which were raised $15 \mathrm{~cm}$ to allow for mushroom development.

Plantain leaf bundles and cassava peels supported the highest mycelial density followed by threshed rice panicle and cotton waste. The highest yield $(280 \mathrm{~g} / \mathrm{kg}$ substrate) was obtained from the plantain leaf bundles, giving a biological conversion efficiency of 25\%. Pinhead formation started 10 and 13 days after spawning on the bundled and chopped plantain leaves, respectively. The mixture of cotton waste and rice straw was the best after the plantain leaves followed by the mixture of cotton waste and corn cob. Yields increased from October to April/May with a maximum of $280 \mathrm{~g} / \mathrm{kg}$ for the plantain leaf bundles in April/May where temperatures ranged from $20.0-36.0^{\circ} \mathrm{C}$ and was very low in August/September, where temperatures ranged from 20.0-32.5ㄷ. Nitrogen content of some substrates was low (0.4$1.0 \%)$ and therefore these substrates may need supplementation.
\end{abstract}

Key words: Volvariella volvacea, fructification, supplemented substrates, high bed method.

\section{INTRODUCTION}

The oil palm mushroom, Volvariella volvacea (Bull. Ex. Fr.) Sing., also called the straw mushroom, is one of the most highly priced and preferred edible mushrooms in Ghana because of its taste, desirable flavour and medicinal value (Apetorgbor and Obodai, 2003). Mushrooms are highly nutritious with high quality protein value, minerals $(\mathrm{P}, \mathrm{K}, \mathrm{Fe})$ folic acid, low in starch, fat and sodium. They are used to supplement meat and fish, and for their flavour in soups and stews. They contain certain compounds which are anti-cancer, anti-viral, anti-hyper and hypotensive. They display ability to lower cholesterol levels in the body (Holden, 1970; Kurtzman, 1975; Oei, 1996).

Traditionally, $V$. volvacea is cultivated in most forest areas using peelings of cassava and cocoyam (Dixon, 1960), oil palm wastes and cocoa husks heaped up in shallow pits and spawned with spore slurry prepared by macerating the mature fruit bodies of the wild mushroom in water (Sawyerr, 1998). These methods of oil palm mushroom production have never been commercialized.

A considerable amount of work has been done using modified methods from Southeast Asia for commercial cultivation of oil palm mushroom in Ghana. Locally available agricultural lignocellulose wastes (maize stover, rice straw, banana/ plantain leaves, oil palm fruit fibre, cocoa bean shells and root tuber peelings) have been used by applying the low bed method to cultivate $V$. volvacea but yields have been low and inconsistent (Odamtten and Obodai, 1995; Sawyerr, 1998). Although the traditional and low bed cultivation methods of $V$. volvacea are well known to mushroom growers, efforts are being made to improve the yield of this popular species by using better $V$. volvacea strains, better substrates and improved cultivation practices. 
This study was conducted to compare the performance of various local substrates and supplements on the growth and yield of the oil palm mushroom using the low and high bed cultivation methods. These substrates are found in abundance in rural communities and if found to give good yield of $V$. volvacea would be used by the rural folks in mushroom production to increase the protein content of their diets and also increase their livelihood.

\section{MATERIALS AND METHODS}

\section{Mushroom culture preparation}

The initial fruiting body (sporophore) of the oil palm mushroom was obtained from decayed oil palm stems on an abandoned farm near the Forestry Research Institute of Ghana, and multiplied using tissue culture on potato dextrose agar (PDA) medium at $32 \pm 2^{\circ} \mathrm{C}$ in the dark for seven days.

\section{Substrates and bed preparation}

Dry rice straw and threshed rice panicle, cotton waste (leftovers from a textile factory), plantain leaves, cassava peels, spear grass, oil palm fruit fibre, Limnocharis flavus (above ground parts), sugarcane bagasse and cocoa bean shells (testa removed from roasted beans at a processing factory) and corn cobs were used as substrates. The dry rice straw and threshed rice panicle, plantain leaves, cassava peels, L. flavus, sugarcane bagasse and spear grass were chopped into pieces (about $3 \mathrm{~cm}$ long); the corn cob was crushed into pieces, while another batch of plantain leaves and rice straw were tied in bundles weighing about $1 \mathrm{~kg}$.

The dry plantain leaves, cassava peels, oil palm fruit fibre, cotton waste, L. flavus, sugarcane bagasse and cocoa bean shells were weighed separately and steeped in water for three hours. The chopped rice straw, chopped rice panicle, spear grass, and rice straw bundles were also weighed separately and soaked in water for 12 hours. After these periods they were removed and drained of excess water until moisture content was about $70 \%$. Cotton waste was teased into small pieces.

Low beds were constructed with a trapezoid mould $(49.0 \mathrm{~cm} \times 38.5 \mathrm{~cm}$ base, $44.0 \mathrm{~cm} \times 25.5 \mathrm{~cm}$ top, $26.5 \mathrm{~cm}$ height). The chopped rice straw and threshed panicle, plantain leaves, cassava peels, oil palm fruit fibre, cotton waste and spear grass were used on the beds separately as single substrates (Fig. 1). The water-soaked materials were sprinkled with grain spawn of the mushroom and covered with thick clean transparent polyethylene sheets. There were three replicates for each treatment.

Bundles of the plantain leaves and rice straw (also as single substrates) were used in preparing high beds. The bundles were arranged horizontally with five bundles in a row and compacted. Grain spawn was sprinkled at intervals at the periphery of the bundles. A second layer of bundles was arranged on top of the first layer with the butt ends opposite to those in the first layer (Fig. 2). Grain spawn was sprinkled at intervals along the periphery of the bundles. The process was repeated until five layers were made. The water-soaked materials were covered with thick transparent polyethylene sheets as done for the low beds.

The different substrates have different textures and contain different levels of chemical constituents. It was therefore found necessary to use them in combinations to provide the needed compactness and aeration and to complement each other's nutrients for the use of the mushroom. Chopped plantain leaves were mixed with oil palm fruit fibre while rice straw was mixed separately with equal quantities (w/w) of cotton waste and cocoa bean shells. Cotton waste was mixed separately with corn cob and sugarcane bagasse. Spear grass was combined in equal proportions with threshed rice panicle while $L$. flavus was mixed with corn cob. These were also used in preparing low beds as done for the single substrates.

Chopped rice straw and threshed rice panicle, spear grass and oil palm fruit fibre were each mixed with $10 \%$ leucaena leaves $(\mathrm{w} / \mathrm{w})$ as supplements. Another batch of oil palm fruit fibre was mixed with $20 \%$ rice husk while another was mixed with $10 \%$ leucaena and $20 \%$ rice husk. They were also used to prepare low beds.

After 7 days the polyethylene sheets were raised about $15 \mathrm{~cm}$ above the beds on poles to reduce excessive heat and carbon dioxide, aerate the compost and provide enough space for fruitbody development. The canal around the beds was moistened with water to initiate development of pinheads. 


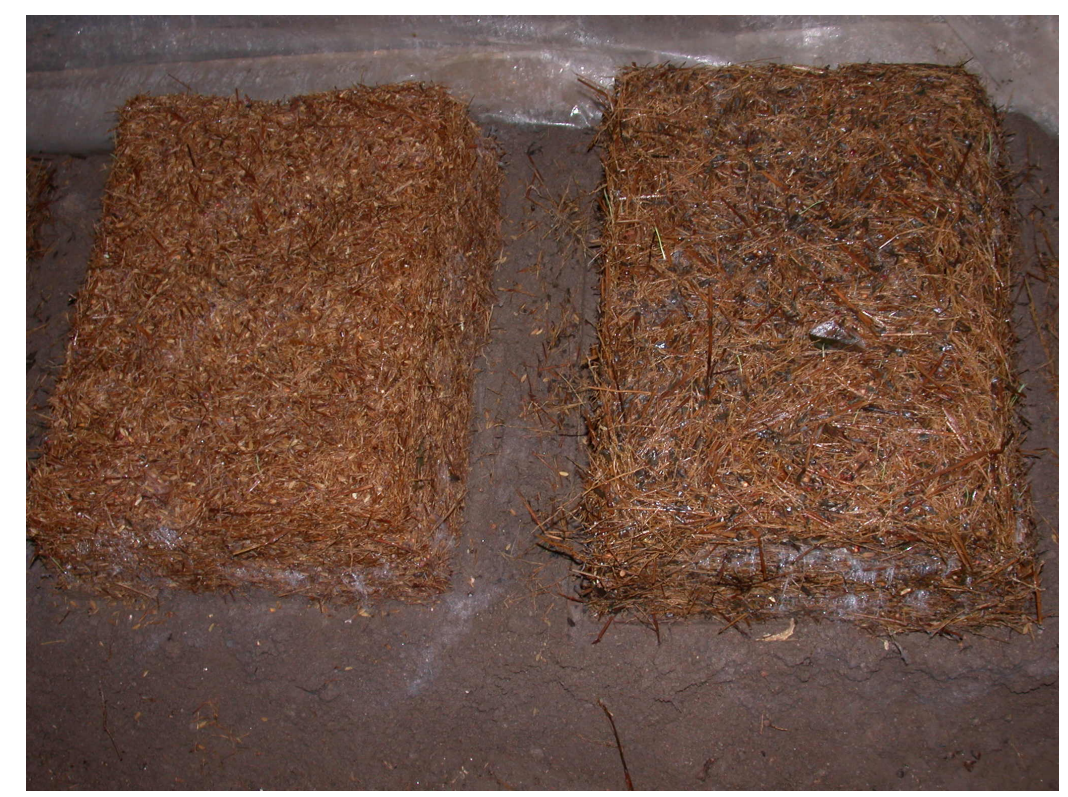

Fig. 1. Low bed of oil palm fruit fibre constructed with trapezoid mould

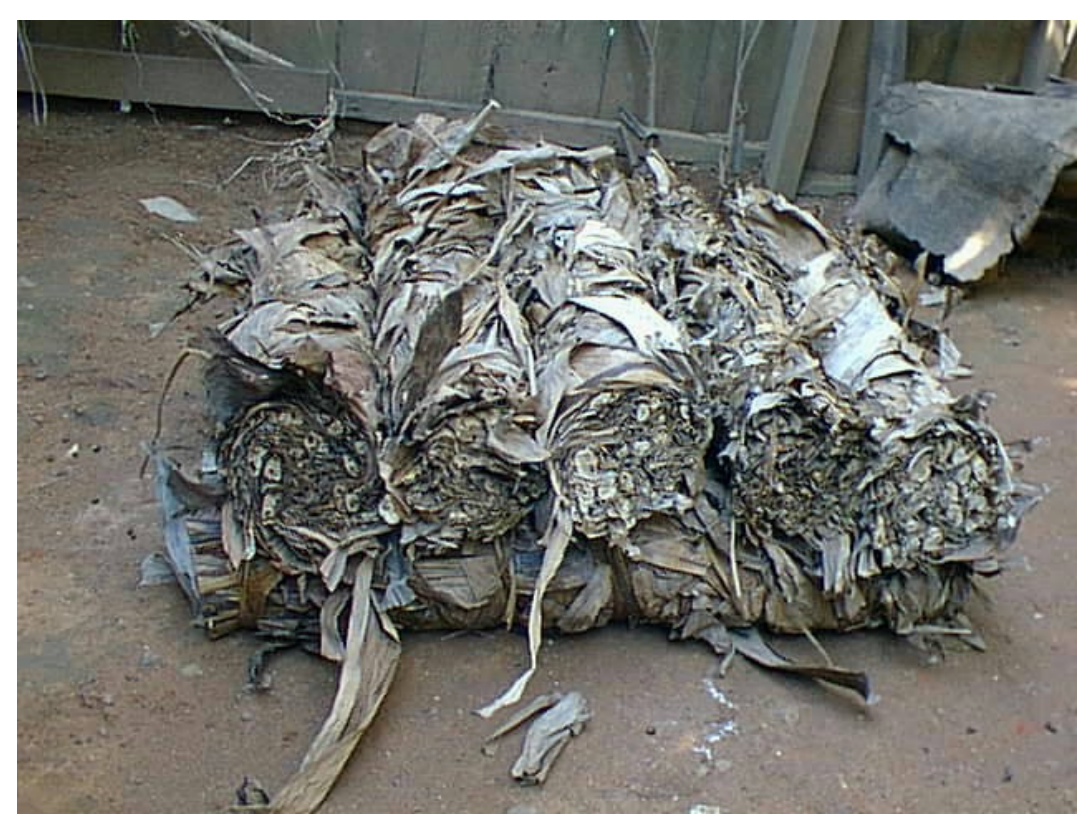

Fig. 2. High bed of layers of plantain leaf bundles

\section{Assessment of growth and yield of mushroom}

Vegetative growth of the mushroom was assessed by visual observation of the mycelia on the substrates and the time taken for pinheads to form after spawning recorded.

Mushrooms were harvested at the elongation stage, cleaned, weighed and the Biological Conversion Efficiency (BCE) (Tschierper and Hartman, 1977) determined using the mathematical relationship:

$$
\mathrm{BCE}=\frac{\text { Weight of fregh mushrooms }}{\text { Dry weight of substrate }} \times 100 \%
$$


To assess the effect of weather on yield of $V$. Volvacea, the mushroom was cultivated on plantain leaf bundles (the substrate that gave the highest yield) all through the year from January to December and the temperature, rainfall and relative humidity values obtained from the Forestry Research Institute of Ghana Weather Station.

\section{Physicochemical analysis of mushroom substrates}

The nitrogen, ash and organic matter of the substrates as well as $\mathrm{C} / \mathrm{N}$ ratio were determined before the experiment and after harvesting the mushrooms. The ash content of the dried substrates was obtained by burning $1.5 \mathrm{~g}$ of each sample at $600^{\circ} \mathrm{C}$ for eight hours in an electric furnace. Total organic matter was determined by calorimetric procedure and organic carbon estimated by calculation based on the van Bemmelen factor while total nitrogen was determined by the Kjedahl method (TAPPI, 1972). The cellulose, hemicellulose and lignin contents were determined by the method described by van Soest (1963). The chemical compositions were determined before and after colonization by the oil palm mushroom.

The $\mathrm{pH}$ was measured before and after the experiment using the supernatant from $1 \mathrm{~g}$ of substrate soaked in $10 \mathrm{ml}$ distilled water for six hours. It was determined using the Microprocessor $\mathrm{pH}$ meter $(\mathrm{pH} 210)$.

\section{Determination of degraded chemical compounds in the substrates}

The percentage organic compound degraded as a result of colonization of the substrates by $V$. volvacea was calculated as follows:

$$
\% \text { degraded compound }=\frac{w^{*}-w_{2}}{w_{1}} \times 100 \%
$$

where $w_{1}=\%$ organic compound before colonization

$\mathrm{w}_{2}=\%$ organic compound after colonization

\section{Statistical analysis}

Data obtained from yield and chemical composition of substrates were subjected to the one-way analysis of variance (ANOVA) in Excel at $\mathrm{P} \leq 0.05$ and differences between means were determined using the least significant difference (LSD) statistics.

\section{RESULTS}

\section{Cultivation of $V$. volvacea fruiting bodies}

\section{(i) Effect of substrate on production of V. volvacea}

Mycelia of $V$. volvacea grew fairly well on a wide range of cellulosic wastes (Table 1). Plantain leaf bundles and cassava peels supported the highest mycelia density followed by the threshed rice panicle and cotton waste. Oil palm fruit fibre, spear grass, rice straw bundle, chopped rice straw and chopped plantain leaves had poor mycelial growth.

Among the nine substrates used the plantain leaves (chopped or bundles) were the best for mushroom production. The highest yield $(280 \mathrm{~g} / \mathrm{kg}$ substrate) was obtained with the plantain leaf bundles, giving a biological conversion efficiency of $25 \%$. The threshed rice panicle yielded $136.4 \mathrm{~g} / \mathrm{kg}$ substrate under the same experimental conditions followed by the cassava peels with a yield of $76.9 \mathrm{~g} / \mathrm{kg}$ substrate. Spear grass, oil palm fruit fibre and cotton waste were poor substrates for V. volvacea, producing less than $10 \mathrm{~g} / \mathrm{kg}$ substrate. The differences in yield produced by the various substrates (except for those between oil palm fruit fibre and spear grass and between spear grass and cotton waste) were significantly different at the $5 \%$ level of significance.

Pinhead formation started 9-10 days after spawning on the cotton waste and rice straw bundles but the former produced a lower yield. The biological efficiency of the cotton waste was $0.3 \%$ while those of the plantain leaf bundles and the chopped rice straw were $25 \%$ and $26.7 \%$, respectively. Pinhead formation started 10 and 13 days after spawning on the plantain leaf bundles and chopped plantain leaves, respectively, with the former producing the highest yield among the substrates investigated (Fig. 3). 
Table 1. Growth and yield of $V$. volvacea on single substrates for 28 days

\begin{tabular}{|l|l|l|l|l|l|l|}
\hline \multirow{2}{*}{ Substrate } & \multicolumn{2}{|c|}{$\mathrm{pH}$} & $\begin{array}{l}\text { Mycelial } \\
\text { density }^{2}\end{array}$ & $\begin{array}{l}\text { Pinhead } \\
\text { formation } \\
\text { (days) }\end{array}$ & $\begin{array}{l}\text { Mean yield } \\
\text { (g/kg substrate) }\end{array}$ & $\begin{array}{l}\text { Biological } \\
\text { Conversion } \\
\text { Efficiency } \\
\text { (\%) }\end{array}$ \\
\cline { 2 - 7 } Initial & Final & & & & \\
\hline Threshed rice panicle & 7.8 & 6.9 & ++ & 15 & $136.4 \pm 0.50^{\mathrm{c}}$ & 10.0 \\
\hline Plantain leaf bundles & 7.7 & 7.8 & +++ & 10 & $280.0 \pm 2.67^{\mathrm{a}}$ & 25.0 \\
\hline $\begin{array}{l}\text { Chopped plantain } \\
\text { leaves }\end{array}$ & 7.7 & 7.9 & + & 13 & $166.7 \pm 3.90^{\mathrm{b}}$ & 15.7 \\
\hline Oil palm fruit fibre & 5.2 & 6.3 & + & 16 & $7.3 \pm 0.20^{\mathrm{g}}$ & 1.6 \\
\hline Spear grass & 6.7 & 6.5 & + & 24 & $5.6 \pm 0.12^{\mathrm{g}, \mathrm{n}}$ & 3.3 \\
\hline Cotton waste & 6.9 & 7.5 & ++ & 9 & $2.9 \pm 0.18^{\mathrm{n}}$ & 0.3 \\
\hline Dry cassava peels & 5.7 & 6.7 & +++ & 20 & $76.9 \pm 0.46^{\mathrm{d}}$ & 20.5 \\
\hline Rice straw bundles & 6.7 & 7.9 & + & 10 & $36.8 \pm 0.20^{\mathrm{e}}$ & 3.7 \\
\hline Chopped rice straw & 7.1 & 8.1 & + & 13 & $26.7 \pm 0.25^{\dagger}$ & 26.7 \\
\hline
\end{tabular}

${ }^{1}$ Values bearing the same letter in superscript are not significantly different at the $5 \%$ significance level

${ }^{2}++$ Very good running growth of mycelia

$+\quad$ Good running growth of mycelia

$+\quad$ Poor running growth of mycelia

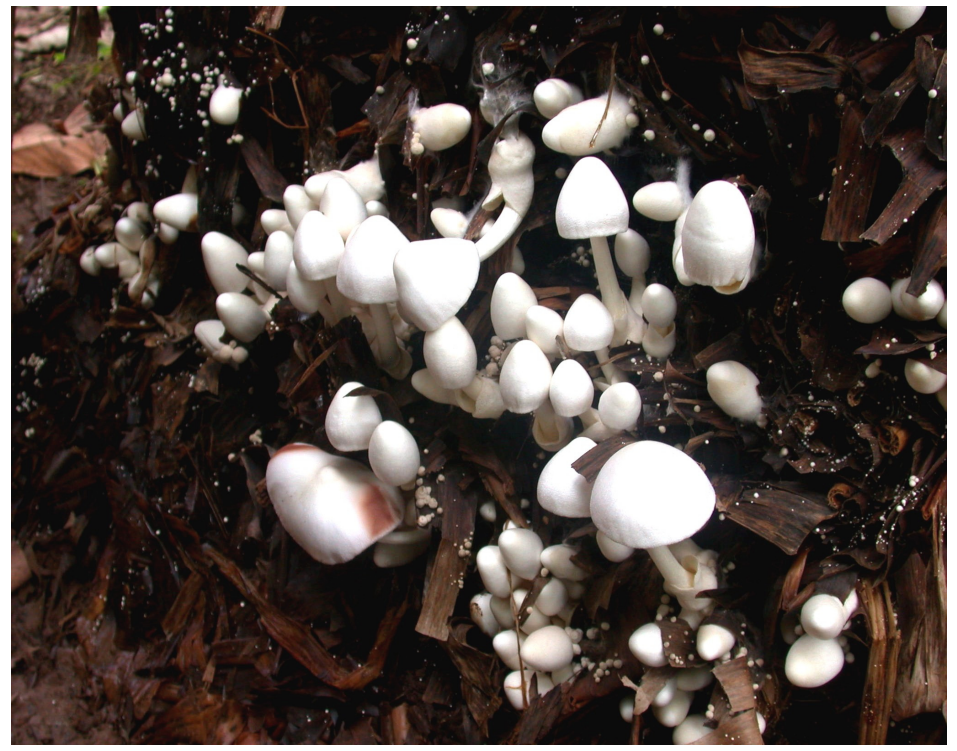

Fig. 3. Developing mushrooms on plantain leaf bundles (13 days after spawning)

\section{(ii) Fructification of $V$. volvacea on combination of substrates}

Mixtures of chopped plantain leaves and oil palm fruit fibre, cotton waste and rice straw, cotton waste and corn cob supported high mycelial density. Spear grass mixed with threshed rice panicle and L. flavus mixed with corn cob gave the poorest mycelial growth (Table 2).

Pinhead formation started nine days after spawning on the mixtures of chopped plantain leaves and oil palm fruit fibre and 10 days on cotton waste and corn cob (Fig. 4). Among the substrates, the mixture of cotton waste and rice straw was the best followed by cotton waste mixed with corn cob. The highest yield $(195.5 \mathrm{~kg})$ was obtained from the mixture of cotton waste and rice straw with Biological Conversion Efficiency of $19.5 \%$ (Table 2) followed by cotton waste mixed with corn cob. Differences in yield by the combination of substrates were all significant at the $5 \%$ significance level. Mixtures of spear grass and threshed rice panicle, rice straw and cocoa bean shells were poor substrates for $V$. volvacea, producing less than $10 \mathrm{~g} / \mathrm{kg}$ substrate. 
Table 2. Growth and yield of $V$. volvacea on mixtures of substrates for 28 days

\begin{tabular}{|c|c|c|c|c|c|c|}
\hline \multirow[t]{2}{*}{ Substrate } & \multicolumn{2}{|c|}{$\mathrm{pH}$} & \multirow{2}{*}{$\begin{array}{l}\text { Mycelial } \\
\text { density }^{2}\end{array}$} & \multirow{2}{*}{$\begin{array}{l}\text { Pinhead } \\
\text { formation } \\
\text { (days) }\end{array}$} & \multirow{2}{*}{$\begin{array}{l}\text { Mean yield } \\
\text { (g/kg substrate) }^{1}\end{array}$} & \multirow{2}{*}{$\begin{array}{l}\text { Biological } \\
\text { Conversion } \\
\text { Efficiency (\%) }\end{array}$} \\
\hline & Initial & Final & & & & \\
\hline $\begin{array}{l}\text { Chopped plantain } \\
\text { leaves + Oil palm } \\
\text { fruit fibre }\end{array}$ & 4.2 & 6.0 & +++ & 9 & $111.1 \pm 0.20^{C}$ & 11.7 \\
\hline $\begin{array}{l}\text { Chopped spear } \\
\text { grass + Chopped } \\
\text { rice panicle }\end{array}$ & 6.9 & 6.8 & + & 24 & $8.3 \pm 0.21^{9}$ & 0.8 \\
\hline $\begin{array}{l}\text { Cotton waste + } \\
\text { rice straw }\end{array}$ & 7.5 & 6.2 & +++ & 12 & $195.5 \pm 0.50^{a}$ & 19.5 \\
\hline $\begin{array}{l}\text { L. flavus + } \\
\text { Corn cob }\end{array}$ & 6.7 & 6.3 & + & 12 & $14.4 \pm 0.10^{e}$ & 0.1 \\
\hline $\begin{array}{l}\text { Cotton waste + } \\
\text { Corn cob }\end{array}$ & 5.3 & 5.9 & +++ & 10 & $124.2 \pm 0.00^{\mathrm{b}}$ & 12.4 \\
\hline $\begin{array}{l}\text { Chopped rice straw } \\
+ \text { Cocoa bean } \\
\text { shells }\end{array}$ & 5.4 & 7.4 & ++ & 20 & $9.8 \pm 0.27^{\dagger}$ & 1.0 \\
\hline $\begin{array}{l}\text { Sugar cane } \\
\text { baggase + Cotton } \\
\text { waste }\end{array}$ & 3.5 & 5.9 & ++ & 12 & $72.7 \pm 1.08^{\mathrm{d}}$ & 7.3 \\
\hline
\end{tabular}

${ }^{1}$ Values bearing the same letter in superscript are not significantly different at the $5 \%$ significance level ${ }^{2}+++\quad$ Very good running growth of mycelia

$+\quad$ Good running growth of mycelia

$+\quad$ Poor running growth of mycelia

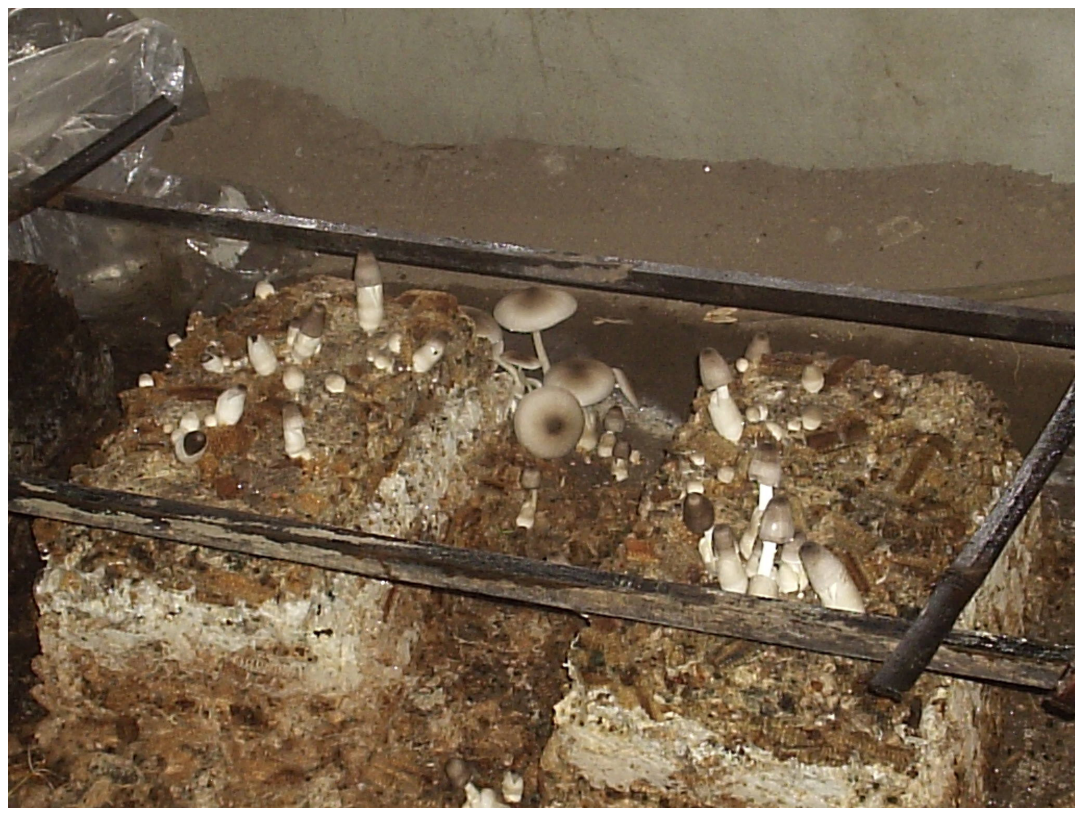

Fig. 4. Developing mushrooms on cotton wastes plus corn cob (13 days after spawning) 


\section{(iii) Fructification of $V$. volvacea on supplemented substrates}

Mycelial growth of $V$. volvacea and mean yield on rice straw (111.1 $/ \mathrm{kg}$ substrate) was improved when supplemented with $10 \%$ leucaena leaves (Table 3 ). Threshed rice panicle supplemented with $10 \%$ leucaena also increased yield $(150 \mathrm{~g} / \mathrm{kg}$ substrate) with pinhead formation starting from 13 days. Besides, there was a vast increase in fruit body formation on spear grass $(40 \mathrm{~g} / \mathrm{kg}$ substrate) when supplemented with $10 \%$ leucaena, with pinhead formation also starting from 13 days (Table 3 ). Even though mycelial growth on supplemented oil palm fruit fibre was not improved there was an increase in yield in all cases of its supplementation.

Table 3. Growth and yield of $V$. volvacea on supplemented substrates

\begin{tabular}{|l|l|l|l|l|l|l|}
\hline \multirow{2}{*}{ Substrate } & \multicolumn{2}{|c|}{$\mathrm{pH}$} & $\begin{array}{l}\text { Mycelia } \\
\text { density }\end{array}$ & $\begin{array}{l}\text { Pinhead } \\
\text { formation } \\
\text { (days) }\end{array}$ & $\begin{array}{l}\text { Mean yield } \\
\text { (g/kg substrate) }\end{array}$ & $\begin{array}{l}\text { Biological } \\
\text { Conversion } \\
\text { Efficiency (\%) }\end{array}$ \\
\cline { 2 - 6 } & Initial & Final & & & & \\
\hline $\begin{array}{l}\text { Chopped rice } \\
\text { straw \& 10\% } \\
\text { Leucaena }\end{array}$ & 6.1 & 7.7 & ++ & 13 & $111.1 \pm 0.45^{\mathrm{b}}$ & 8.9 \\
\hline $\begin{array}{l}\text { Chopped spear } \\
\text { grass \& 10\% } \\
\text { Leucaena }\end{array}$ & 6.3 & 7.2 & + & 13 & $40.0 \pm 0.61^{\mathrm{e}}$ & 4.0 \\
\hline $\begin{array}{l}\text { Threshed rice } \\
\text { panicle \& 10\% } \\
\text { Leucaena }\end{array}$ & 6.5 & 7.2 & ++ & 13 & $150.0 \pm 0.36^{\mathrm{a}}$ & 15.0 \\
\hline $\begin{array}{l}\text { Oil palm fruit fibre } \\
\text { \& 10\% Leucaena }\end{array}$ & 5.4 & 6.3 & + & 15 & $50.0 \pm 0.31^{\mathrm{d}}$ & 5.0 \\
\hline $\begin{array}{l}\text { Oil palm fruit fibre } \\
\text { \& 20\% Rice husk }\end{array}$ & 5.7 & 6.2 & + & 16 & $36.0 \pm 0.20^{\dagger}$ & 3.6 \\
\hline $\begin{array}{l}\text { Oil palm fruit fibre } \\
\text { \& 10\% Leucaena } \\
\& 20 \% \text { Rice husk }\end{array}$ & 6.0 & 6.0 & + & 15 & $68.0 \pm 0.58^{\mathrm{c}}$ & 6.8 \\
\hline
\end{tabular}

${ }^{1}$ Values bearing the same letter in superscript are not significantly different at the $5 \%$ significance level

${ }^{2}+++\quad$ Very good running growth of mycelia

$+\quad$ Good running growth of mycelia

$+\quad$ Poor running growth of mycelia

\section{(iv) Yield pattern of $V$. volvacea on plantain leaf bundles during the year}

Weather conditions of a locality do influence mushroom production and hence it was considered worthwhile to study the influence of temperature, rainfall and relative humidity on fruit body production of $V$. volvacea during the year. Cultivation trials were conducted on plantain leaf bundles from January to December. Yield increased from October to April/May with a maximum of $280 \mathrm{~g} / \mathrm{kg}$ substrate in April/May where temperatures ranged from $20.0-36.0^{\circ} \mathrm{C}$. The yield was very low in August/September but gradually increased in September/October, when temperatures and relative humidity were more favourable (Table 4). Pinhead formation occurred from 13 to 20 days. There were significant differences in yield between the periods of cultivation at $5 \%$ level of significance except for the months of June-July and November-December as well as June/July and October. 
Table 4. Yield of $V$. volvacea under varying weather conditions* on plantain leaf bundles

\begin{tabular}{|l|l|l|l|l|l|l|}
\hline Month & $\begin{array}{l}\text { Range of } \\
\text { maximum } \\
\text { temperature } \\
\left({ }^{\circ} \mathrm{C}\right)\end{array}$ & $\begin{array}{l}\text { Range of } \\
\text { minimum } \\
\text { temperature } \\
\left({ }^{\circ} \mathrm{C}\right)\end{array}$ & Rainfall $(\mathrm{mm})$ & $\begin{array}{c}\text { Relative } \\
\text { Humidity } \\
(\%)\end{array}$ & $\begin{array}{c}\text { Pinhead } \\
\text { formation } \\
\text { (days) }\end{array}$ & $\begin{array}{c}\text { Mean yield } \\
(\mathrm{g} / \mathrm{kg} \\
\text { substrate })^{1}\end{array}$ \\
\hline $\begin{array}{l}\text { January/ } \\
\text { February }\end{array}$ & $30.0-36.0$ & $20.0-25.0$ & $5.0-04.0$ & $89.9-90.6$ & 13 & $190.0 \pm 0.02^{\mathrm{b}}$ \\
\hline April/May & $28.0-36.0$ & $20.0-25.0$ & $125.1-143.1$ & $85.6-87.6$ & 13 & $280.0 \pm 0.03^{\mathrm{a}}$ \\
\hline June/July & $25.0-32.5$ & $19.0-24.0$ & $55.0-166.0$ & $89.1-90.1$ & 18 & $170.0 \pm 0.01^{\mathrm{c}, \mathrm{d}}$ \\
\hline $\begin{array}{l}\text { August/ } \\
\text { September }\end{array}$ & $25.5-32.5$ & $20.0-24.0$ & $198.3-203.5$ & $91.6-93.2$ & 20 & $110.0 \pm 0.05^{\mathrm{g}}$ \\
\hline $\begin{array}{l}\text { September/ } \\
\text { October }\end{array}$ & $26.0-33.0$ & $20.0-24.0$ & $198.3-203.5$ & $87.7-93.2$ & 17 & $140.0 \pm 0.00^{\dagger}$ \\
\hline $\begin{array}{l}\text { October } \\
\text { Ond }\end{array}$ & $26.0-33.0$ & $20.0-24.0$ & $198.3-203.5$ & $87.7-93.2$ & 14 & $160.0 \pm 0.03^{\mathrm{d}, \mathrm{e}}$ \\
\hline $\begin{array}{l}\text { November/ } \\
\text { December }\end{array}$ & $29.5-33.5$ & $15.0-24.0$ & $6.0-155.5$ & $83.4-85.4$ & 14 & $180.0 \pm 0.02^{\mathrm{c}}$ \\
\hline
\end{tabular}

*Weather data: Forestry Research Institute of Ghana Weather Station, Fumesua

${ }^{1}$ Values bearing the same letter in superscript are not significantly different at the $5 \%$ significance level

\section{(v) Chemical characteristics of substrates}

Major components of the substrates included cellulose, hemicellulose, lignin, ash and organic matter which were high at the onset of the experiment but dropped after fruit body formation (Table 5). Cellulose content of corn cob was the most degraded $(46.7 \%)$ and that of the oil palm fruit fibre was the least degraded (1.5\%) for the single substrates. The hemicellulose content of corn cob was the most degraded (11.0\%) for the single substrates while that in the rice straw was the least degraded (17\%). The $\mathrm{C} / \mathrm{N}$ ratio differed for the various substrates. The initial $\mathrm{C} / \mathrm{N}$ ratio of the substrates was highest for corn cob (148.6) but reduced drastically to 51.7 by the end of the harvesting period (Table $5)$. Oil palm fruit fibre had the highest $\mathrm{C} / \mathrm{N}$ ratio (133.8) at harvesting of the mushrooms. Lignin content was low in cotton waste but high in cocoa bean shell, sugar cane bagasse and oil palm fruit fibre (Table 5). Lignin was most degraded in threshed rice panicle $(41.0 \%)$ followed by that in rice straw and plantain leaves.

Lignin content of mixture of plantain leaves and oil palm fruit fibre was the most degraded (30.6\%) among the mixture of substrates followed by that of cotton waste and rice straw mixture $(30.0 \%)($ Table 6$)$. C/N ratio was highest in mixture of spear grass and threshed rice panicle (106.4) followed by the mixtures of cotton waste and sugar cane bagasse $(77.8 \%)$ and plantain leaves and oil palm fruit fibre (74.9). These reduced drastically at harvest. Cellulose and hemicellulose contents of mixtures of Limnocharis and corn cob were the most degraded (31.3\% to $19.7 \%$ and 34.25 to $25.1 \%$, respectively) followed by cocoa bean shells and rice straw $(28.9 \%$ to $18.3 \%$ and $16.9 \%$ to $12.2 \%$, respectively) Table 6 ).

For the supplemented substrates, oil palm fruit fibre and rice husk mixture were the most degraded giving an improvement over that of oil palm fruit fibre alone. $\mathrm{C} / \mathrm{N}$ ratio for threshed rice panicle and leucaena mixture was the least among the substrates at the beginning of the experiment (34.2) as well as at the end of the harvesting period (25.5) (Table 7). There was an improvement in breakdown of cellulose when oil palm fruit fibre was supplemented with rice husk and leucaena. Degradation also improved in cellulose and lignin content of oil palm fruit fibre when supplemented with rice husk but mycelia growth and yield were still low (Table 3).

Nitrogen content of substrates and their combinations was low $(0.4-1.2 \%$ and $0.5-1.0 \%$, respectively) at start of experiment (Tables 5 and 6). For each of cellulose, hemicellulose, lignin and $\mathrm{C} / \mathrm{N}$ ratio, there is a significant difference $(\mathrm{P}<0.0001)$ between the constituents of the substrate at time of spawning and at harvesting of mushrooms. 
Table 5. Chemical composition of single substrates used for cultivation of $V$. volvacea

\begin{tabular}{|c|c|c|c|c|c|c|c|c|c|c|c|c|c|c|}
\hline \multirow[b]{3}{*}{ Substrate } & \multicolumn{14}{|c|}{ Chemical composition of substrates before and after cultivation (\%)* } \\
\hline & \multicolumn{2}{|c|}{ Cellulose } & \multicolumn{2}{|c|}{ Hemi-cellulose } & \multicolumn{2}{|c|}{ Lignin } & \multicolumn{2}{|c|}{ Ash } & \multicolumn{2}{|c|}{ Organic matter } & \multicolumn{2}{|c|}{$\mathrm{C} / \mathrm{N}$ ratio } & \multicolumn{2}{|c|}{ Nitrogen } \\
\hline & 1 & 2 & 1 & 2 & 1 & 2 & 1 & 2 & 1 & 2 & 1 & 2 & 1 & 2 \\
\hline $\begin{array}{c}\text { Threshed rice } \\
\text { panicle }\end{array}$ & $38.3^{\mathrm{a}}$ & $31.2^{j}$ & $31.4^{a}$ & $27.6^{j}$ & $6.1^{\mathrm{a}}$ & $3.6^{a}$ & $22.5^{\mathrm{a}}$ & $18^{a}$ & $77.5^{\mathrm{a}}$ & $82^{a}$ & $56.3^{\mathrm{a}}$ & $79.5^{b}$ & $0.8^{\mathrm{a}}$ & $0.6^{a}$ \\
\hline $\begin{array}{c}\text { Plantain } \\
\text { leaves }\end{array}$ & $26.5^{c}$ & $21.5^{n}$ & $16.7^{b}$ & $13.3^{l}$ & $5.0^{a}$ & $3.0^{a}$ & $14.2^{b}$ & $12.3^{b}$ & $85.8^{b}$ & $87.7^{b}$ & $71.3^{c}$ & $85.0^{d}$ & $0.7^{\mathrm{a}}$ & $0.6^{\mathrm{a}}$ \\
\hline Cassava peels & $15.0^{d}$ & $11.2^{0}$ & $6.9^{c}$ & $6.0^{c}$ & $12.1^{\mathrm{b}}$ & $10.6^{b}$ & $15^{\mathrm{b}}$ & $12.4^{\mathrm{b}}$ & $85^{b}$ & $87.6^{\mathrm{b}}$ & $49.4^{\mathrm{e}}$ & $63.8^{\dagger}$ & $1.0^{\mathrm{b}}$ & $0.8^{b}$ \\
\hline $\begin{array}{l}\text { Oil palm } \\
\text { fruit fibre }\end{array}$ & $41.2^{\mathrm{e}}$ & $40.6^{\mathrm{e}}$ & $30.5^{a}$ & $30.4^{a}$ & $16.9^{c}$ & $15.4^{c}$ & $8.2^{c}$ & $8^{c}$ & $91.8^{c}$ & $92^{c}$ & $106.8^{g}$ & $\underset{\mathrm{h}}{133.8}$ & $0.5^{\mathrm{C}}$ & $0.4^{\mathrm{C}}$ \\
\hline Spear grass & $28.9^{\dagger}$ & $20.3^{n}$ & $18.5^{\mathrm{b}}$ & $11.4^{\mathrm{g}, \mathrm{m}}$ & $7.6^{\mathrm{a}, \mathrm{d}}$ & $5.1^{\mathrm{a}, \mathrm{d}}$ & $12.4^{\mathrm{d}}$ & $16^{\mathrm{d}}$ & $87.6^{b}$ & $84^{a, b}$ & $121.6^{\prime}$ & $97.7^{J}$ & $0.4^{\mathrm{C}}$ & $0.5^{\mathrm{C}}$ \\
\hline $\begin{array}{l}\text { Cocoa bean } \\
\text { shells }\end{array}$ & $25.2^{g}$ & $20.5^{n}$ & $8.9^{c}$ & $8.0^{\mathrm{g}}$ & $26.5^{\mathrm{e}}$ & $25^{e}$ & $9.8^{\mathrm{C}}$ & $13.7^{\mathrm{e}}$ & $90.2^{c}$ & $86.4^{b}$ & $42.9^{k}$ & $29.8^{\prime}$ & $1.2^{b}$ & $1.7^{d}$ \\
\hline L. flavus & $24.5^{\mathrm{g}}$ & $17.9^{p}$ & $16.5^{\mathrm{D}}$ & $12.8^{\mathrm{g}, \mathrm{I}}$ & $5.2^{a}$ & $4.1^{\mathrm{a}}$ & $12^{d}$ & $16.6^{\mathrm{d}}$ & $88^{D}$ & $83.4^{\mathrm{a}, \mathrm{b}}$ & $51.2^{a}$ & $38.8^{k}$ & $1.0^{\mathrm{b}}$ & $1.2^{\mathrm{e}}$ \\
\hline Corn cob & $39.2^{\mathrm{a}, \mathrm{b}}$ & $20.9^{n}$ & $46.3^{\mathrm{e}}$ & $41.2^{n}$ & $10.4^{a, b}$ & $8.9^{a, b}$ & $8^{c}$ & $12.9^{b, e}$ & $92^{c}$ & $87.1^{\mathrm{b}}$ & $148.6^{\mathrm{m}}$ & $51.7^{a}$ & $0.4^{\mathrm{C}}$ & $1.0^{\dagger}$ \\
\hline Rice straw & $32.0^{\mathrm{h}}$ & $28.5^{\dagger}$ & $22.9^{\dagger}$ & $22.5^{\dagger}$ & $6.9^{\mathrm{a}}$ & $4.8^{\mathrm{a}}$ & $13.9^{b}$ & $19.7^{\mathrm{a}}$ & $86.1^{\mathrm{b}}$ & $80.3^{\mathrm{a}}$ & $62.6^{\dagger}$ & 24.8 & $0.8^{\mathrm{a}}$ & $1.9^{9}$ \\
\hline Cotton waste & $32.5^{\mathrm{h}}$ & $28.6^{f}$ & $12.4^{g, l}$ & $10.3^{m}$ & $0.4^{f}$ & $0.2^{f}$ & $8.6^{c}$ & $14^{\mathrm{e}}$ & $91.4^{\mathrm{c}}$ & $85.9^{b}$ & $44.7^{k}$ & 36.2 & $1.2^{b}$ & $1.4^{\mathrm{h}}$ \\
\hline $\begin{array}{c}\text { Sugar cane } \\
\text { bagasse }\end{array}$ & $32.8^{k}$ & $26.4^{c}$ & $18.3^{b}$ & $14.7^{\prime}$ & $20.1^{c}$ & $19.3^{c}$ & $6.2^{c}$ & $12.4^{\mathrm{a}}$ & $93.8^{a, c}$ & $87.6^{a}$ & $79.0^{p}$ & $43.9^{k}$ & $0.7^{\mathrm{a}}$ & $1.2^{\mathrm{e}}$ \\
\hline
\end{tabular}

*Values bearing the same letter in columns 1 and 2 for each chemical component are not significantly different at the $5 \%$ level by LSD.

1. Substrate at start of experiment

2. Substrate at end of experiment 
Table 6. Chemical composition of mixtures of substrates used for cultivation of $V$. volvacea

\begin{tabular}{|c|c|c|c|c|c|c|c|c|c|c|c|c|c|c|}
\hline \multirow[b]{3}{*}{ Substrate } & \multicolumn{14}{|c|}{ Chemical composition of substrates before and after cultivation (\%) } \\
\hline & \multicolumn{2}{|c|}{ Cellulose } & \multicolumn{2}{|c|}{ Hemi-cellulose } & \multicolumn{2}{|c|}{ Lignin } & \multicolumn{2}{|c|}{ Ash } & \multicolumn{2}{|c|}{ Organic matter } & \multicolumn{2}{|c|}{$\mathrm{C} / \mathrm{N}$ ratio } & \multicolumn{2}{|c|}{ Nitrogen } \\
\hline & 1 & 2 & 1 & 2 & 1 & 2 & 1 & 2 & 1 & 2 & 1 & 2 & 1 & 2 \\
\hline $\begin{array}{l}\text { Cotton waste + } \\
\text { Corn cob }\end{array}$ & $34.5^{i}$ & $23.6^{g}$ & $30.0^{a}$ & $23.9^{f}$ & $9.2^{a, b}$ & $7.2^{a, b}$ & $8.2^{\mathrm{a}}$ & $12.4^{\mathrm{a}}$ & $91.8^{\mathrm{a}}$ & $87.6^{a}$ & $67.7^{f}$ & $42.1^{\mathrm{k}, \mathrm{q}}$ & $0.8^{a}$ & $1.2^{\mathrm{e}}$ \\
\hline $\begin{array}{l}\text { L. flavus + Corn } \\
\text { cob }\end{array}$ & $31.3^{j}$ & $19.7^{n}$ & $34.2^{h}$ & $25.1^{f, j}$ & $8.2^{a, b}$ & $7.2^{a, b}$ & $11.5^{b}$ & $21.2^{b}$ & $88.6^{b}$ & $79.0^{b}$ & $71.5^{\mathrm{f} p \mathrm{p}}$ & $32.3^{n}$ & $0.7^{\mathrm{a}}$ & $1.4^{\mathrm{h}}$ \\
\hline $\begin{array}{l}\text { Plantain leaves } \\
+ \text { Oil palm fruit } \\
\text { fibre }\end{array}$ & $28.0^{f}$ & $23.4^{\mathrm{g}}$ & $18.1^{b}$ & $15.0^{\prime}$ & $6.2^{a}$ & $4.3^{a}$ & $13.6^{b}$ & $11.9^{b}$ & $86.4^{b}$ & $87.9^{b}$ & $74.9^{f, p}$ & $89.9^{\mathrm{d}, \mathrm{s}}$ & $0.7^{a, b}$ & $0.6^{a}$ \\
\hline $\begin{array}{l}\text { Cotton waste + } \\
\text { Rice straw }\end{array}$ & $32.7^{k}$ & $27.2^{c}$ & $20.9^{i}$ & $19.0^{k}$ & $6.0^{a}$ & $4.2^{a}$ & $10.5^{\mathrm{b}}$ & $12.9^{a}$ & $89.5^{a, b}$ & $87.1^{\mathrm{a}}$ & $52.0^{a}$ & $35.9^{k}$ & $1.0^{b}$ & $1.4^{\mathrm{h}}$ \\
\hline $\begin{array}{l}\text { Cocoa bean } \\
\text { shells + Rice } \\
\text { straw }\end{array}$ & $28.9^{f}$ & $18.3^{p}$ & $16.9^{b}$ & $12.2^{g, l}$ & $18.6^{c}$ & $17.0^{c}$ & $11.2^{b}$ & $16.5^{c}$ & $88.8^{a, b}$ & $83.5^{c}$ & $50.6^{a}$ & $33.9^{n}$ & $1.0^{b}$ & $1.4^{\mathrm{h}}$ \\
\hline $\begin{array}{l}\text { Cotton waste + } \\
\text { Sugarcane } \\
\text { bagasse }\end{array}$ & $38.0^{a}$ & $30.4^{j}$ & $24.3^{f}$ & $21.0^{\mathrm{l}, \mathrm{k}}$ & $15.5^{c}$ & $14.4^{c}$ & $3.7^{d}$ & $7.2^{d}$ & $96.3^{c}$ & $92.8^{a}$ & $77.8^{p}$ & $38.8^{q}$ & $0.7^{\mathrm{a}}$ & $1.4^{\mathrm{h}}$ \\
\hline $\begin{array}{l}\text { Spear grass + } \\
\text { Threshed rice } \\
\text { panicle }\end{array}$ & $36.4^{\prime}$ & $30.5^{j}$ & $20.0^{k}$ & $22.4^{f}$ & $7.2^{a}$ & $5.3^{a}$ & $15.8^{e}$ & $18^{e}$ & $84.2^{d}$ & $82.0^{b, c}$ & $106.4^{g}$ & $59.8^{f}$ & $0.5^{c}$ & $0.8^{b}$ \\
\hline
\end{tabular}

*Values bearing the same letter in columns 1 and 2 for each chemical component are not significantly different at the $5 \%$ level by LSD.

1. Substrate at start of experiment

2. Substrate at end of experiment 
Table 7. Chemical composition of supplemented substrates used for cultivation of $V$. volvacea

\begin{tabular}{|c|c|c|c|c|c|c|c|c|c|c|c|c|c|c|}
\hline \multirow{3}{*}{ Substrate } & \multicolumn{14}{|c|}{ Chemical composition of substrates before and after cultivation (\%)* } \\
\hline & \multicolumn{2}{|c|}{ Cellulose } & \multicolumn{2}{|l|}{$\begin{array}{l}\text { Hemi- } \\
\text { cellulose }\end{array}$} & \multicolumn{2}{|c|}{ Lignin } & \multicolumn{2}{|c|}{ Ash } & \multicolumn{2}{|c|}{ Organic matter } & \multicolumn{2}{|l|}{$\mathrm{C} / \mathrm{N}$ ratio } & \multicolumn{2}{|c|}{ Nitrogen } \\
\hline & 1 & 2 & 1 & 2 & 1 & 2 & 1 & 2 & 1 & 2 & 1 & 2 & 1 & 2 \\
\hline $\begin{array}{l}\text { Oil palm fruit fibre } \\
+ \text { Rice husk }\end{array}$ & $44.2^{\mathrm{m}}$ & $18.8^{n, p}$ & $26.6^{\mathrm{j}}$ & $23.4^{f}$ & $17.0^{c}$ & $13.2^{b}$ & $7.5^{\mathrm{a}}$ & $13.5^{\mathrm{a}}$ & $92.5^{\mathrm{a}}$ & $86.5^{\mathrm{a}}$ & $109.7^{\mathrm{g}}$ & $44.9^{k}$ & $0.5^{\mathrm{C}}$ & $0.5^{c}$ \\
\hline $\begin{array}{l}\text { Oil palm fruit fibre } \\
+ \text { Rice husk + } \\
\text { Leucaena }\end{array}$ & $44.1^{\mathrm{m}}$ & $22.4^{\mathrm{a}, \mathrm{g}}$ & $24.5^{f}$ & $19.0^{k}$ & $17.1^{c}$ & $14.7^{b, c}$ & $16.2^{b}$ & $18.6^{\mathrm{b}}$ & $83.8^{\mathrm{b}}$ & $81.4^{b}$ & $44.3^{k}$ & $30.7^{a, r}$ & $1.1^{\mathrm{b}}$ & $1.1^{e, i}$ \\
\hline $\begin{array}{l}\text { Rice straw + } \\
\text { Leucaena }\end{array}$ & $40.0^{b}$ & $30.3^{j}$ & $21.5^{i}$ & $18.8^{b, k}$ & $11.2^{b}$ & $10.2^{a, b}$ & $18.3^{c}$ & $22.3^{c}$ & $81.2^{b}$ & $77.7^{\mathrm{c}}$ & $36.9^{n}$ & $26.9^{1, r}$ & $1.3^{d}$ & $1.2^{\mathrm{e}}$ \\
\hline $\begin{array}{l}\text { Threshed rice } \\
\text { panicle }+ \\
\text { Leucaena }\end{array}$ & $39.9^{b}$ & $31.3^{j}$ & $22.9^{f, i}$ & $20.0^{1, k}$ & $10.7^{b}$ & $10.3^{a, b}$ & $23.5^{d}$ & $22.9^{c}$ & $76.6^{c}$ & $77.1^{c}$ & $34.2^{r, n}$ & $25.5^{1, r}$ & $1.3^{d}$ & $1.3^{\mathrm{e}, \mathrm{h}}$ \\
\hline $\begin{array}{l}\text { Spear grass + } \\
\text { leucaena }\end{array}$ & $31.2^{j}$ & $22.5^{\mathrm{g}}$ & $21.8 \mathrm{i}$ & $12.2^{\mathrm{g}, \mathrm{l}}$ & $7.5^{\mathrm{a}, \mathrm{d}}$ & $6.5^{\mathrm{a}}$ & $12.9^{b}$ & $14.8^{e}$ & $88.5^{b}$ & $86.4^{b}$ & $96.3^{\mathrm{j}, \mathrm{s}}$ & $98.5^{\mathrm{j}, \mathrm{s}}$ & $0.9^{b, c}$ & $0.9^{b, c}$ \\
\hline $\begin{array}{l}\text { Oil palm fruit fibre } \\
+ \text { leucaena }\end{array}$ & $42.6^{b, m}$ & $40.3^{b}$ & $32.5^{\mathrm{a}, \mathrm{h}}$ & $31.0^{j}$ & $15.6^{c}$ & $13.4^{b, c}$ & $8.5^{c}$ & $7.9^{a, c}$ & $87.3^{b}$ & $90.4^{c}$ & $89.9^{s}$ & $120.5^{i}$ & $0.8^{b}$ & $0.7^{a, b}$ \\
\hline
\end{tabular}

*Values bearing the same letter in columns 1 and 2 for each chemical component are not significantly different at the $5 \%$ level by LSD.

1. Substrate at start of experiment

2. Substrate at end of experiment 


\section{DISCUSSION}

The earliest pinhead formation time for the single substrates occurred 9-10 days after spawning on cotton waste, rice straw and plantain leaf bundles. Cotton waste produced the lowest yield with a Biological Conversion Efficiency (BCE) of $0.3 \%$ while the plantain leaf bundles gave the highest yield of the substrates investigated with a BCE of $25 \%$. The low yield from cotton waste is in contrast with the findings of Chang (1983) that cotton waste compost gave a higher and more stable yield than other agricultural by-products. In Chang's work, the substrates were composted prior to use but in the present study neither the cotton waste nor any of the substrates was composted.

The low yield observed for cotton waste as a single substrate in this study might be due to inadequate aeration since the substrate became compact on wetting. It therefore performed better on mixing with rice straw or corn cob which gave BCE of $19.5 \%$ and $12.4 \%$ respectively. Chang (1983) therefore recommended that cotton waste/cotton-seed hulls should be mixed with paddy straw or bagasse for composting for growth of $V$. volvacea. Other reports (Quimio, 1986; Quimio et al., 1990) found that the BCE of pure cotton waste ranged from 25 to $50 \%$ while that of rice and banana leaves ranged from 10 to 15\%. In our work however, the plantain leaves (which should have a similar composition as the banana leaves) however, gave the highest BCE. Pinhead formation started 13 days after spawning on the chopped plantain leaves and chopped rice straw. The higher yield produced on plantain leaf bundles might be due to its higher proportion of cellulose and compactness on wetting.

Cotton waste mixed with rice straw gave a BCE of 19.5\%. Chang (1978) found that mixture of rice straw and cotton waste gave a BCE of $21.8-27.0 \%$ as against $8.4-28.3 \%$ BCE from rice straw alone. Quimio et al. (1990) noted that with outdoor cultivation however, only 10 to15\% BCE is expected using rice straw or banana leaves as growing substrates. Sugarcane bagasse mixed with cotton waste gave a yield of $72.7 \mathrm{~g} / \mathrm{kg}$ substrate with a BCE of $7.3 \%$.

Among the seven substrates used plantain leaf bundles/chopped plantain leaves were the best for $V$. volvacea production. $280 \mathrm{~g} / \mathrm{kg}$ substrate was obtained from the plantain leaf bundles with BCE of $25 \%$. Odamtten and Obodai (1995) obtained a yield of $491.5 \mathrm{~g}$ of $\mathrm{V}$. volvacea fruiting bodies on dry banana leaves after 13 days and yield thereafter declined; BCE of the substrate was $43.0 \%$.

Threshed rice panicle and chopped rice straw supplemented with $10 \%$ leucaena increased yield to $150 \mathrm{~g} / \mathrm{kg}$ substrate and $111.1 \mathrm{~g} / \mathrm{kg}$ substrate, respectively which gave higher yields over the single substrates. Oil palm fruit fibre mixed with supplements gave moderate yields for $V$. volvacea, producing yields between $36.0 \mathrm{~g} / \mathrm{kg}$ and $68.0 \mathrm{~g} / \mathrm{kg}$ substrate. Graham and Chen (1974) reported a yield of $0.02 \mathrm{~g} / \mathrm{kg}$ substrate from a $32 \mathrm{~cm}$ long bed of oil palm fruit fibre waste.

Nitrogen and moisture contents of substrates and their combinations were low $(0.4-1.2 \%$ and $0.5-1.0 \%$, respectively). A report by Kurtzman and Chang-Ho (1982) showed that Volvariella requires very little nitrogen and that the nitrogen provided by rice straw and cotton wastes (1.4\%) plus that provided during composting and spawn running is sufficient for its growth. Therefore, the substrates used in these experiments may not need nitrogenous supplements like leucaena leaves. Ranged and Jandaik (1977) reported a steady increase in nitrogen/protein content of substrates during spawn running and then a decrease during cropping period.

The varying yield of $V$. volvacea in the different months of the year indicates that weather conditions are closely associated with the production of fruitbodies. Yield increased from October to April/May with a maximum yield of $280 \mathrm{~g} / \mathrm{kg}$ substrate in April/May and was very low in August to early September. Environmental temperature and moisture therefore appear to play a significant role in the production of $V$. volvacea (Purkayasthia et al., 1981).

\section{CONCLUSION}

The plantain leaf bundles and cassava peels supported the highest mycelial growth among the single substrates while the combination of chopped plantain leaves plus oil palm fruit fibre, cotton waste plus rice straw, and cotton waste plus corn cob gave the highest among the mixed substrates.

The plantain leaves (chopped or bundles) were the best among the substrates for mushroom production. The plantain leaf bundles gave the highest yield of $280 \mathrm{~g} / \mathrm{kg}$ substrate followed by the mixture of cotton waste plus rice straw with a yield of $195.5 \mathrm{~g} / \mathrm{kg}$ and the chopped plantain leaves with $166.7 \mathrm{~g} / \mathrm{kg}$ yield. Threshed rice panicle and rice straw gave good yields when supplemented with leucaena. 


\section{REFERENCES}

Ali M. A., Khan, D. A. and Khan S. M. (1982). Performance of Chinese mushroom (Volvariella volvacea) on various substrates at Faisalabad, Pakistan. Mushroom News-letter for the Tropics 2 (4):5-9.

Apetorgbor M. M. and Obodai M. (2003). Mushroom consumption in Southern Ghana. Proceedings of the $21^{\text {st }}$ Biennial Conference of Ghana Science Association, KNUST, Kumasi, Ghana, $4^{\text {th }}-7^{\text {th }}$ August, 2003. Pg. 100.

Chang S. T. (1978). Cultivation of Volvariella volvacea from cotton waste compost. Mush. Sci. 10 (II): 609-618.

Chang S. T. (1983). Prospects of Volvariella volvacea cultivation. Mushroom Newsletter for the Tropics 4 (2): 5-8.

Dixon P. A. (1960). Volvariella volvacea 'Abe-mire'. Universitas 4: 51-52.

Garo V. M. (1964). A comparative study of Volvariella esculenta on the suitability of rice straw, dried banana stalks, banana leaves, wheat straw, water hyacinth and sugarcane bagasse. Bres. Production. (Abst) CLSU Scientific Journal 1 (12):130.

Graham K. M. and Chen Y. Y. (1974). Studies on the padi mushroom (Volvariella volvacea). II. Effect of bed depth on yield in oil palm pericarp waste. Mal. Agric. Research 3: 1-6.

Holden M. (1970). Notes on the agaric flora of Ghana. Journal of the West African Science Association 15:25-34.

Kurtzman R. H. (1975). Mushrooms as a source of food protein. In: Friedman, M. (ed.), Protein nutritional quality of foods and feeds. Marcel Dekker Inc., New York.

Kurtzman R. H. and Chang-Ho Y. (1982). In: Tropical Musrooms: Biological nature and cultivation methods, (S. T. Chang and T. H. Quimio, eds.) Chinese University Press, Hong Kong.

Oei P. (1966). Mushroom cultivation, with special emphasis on appropriate techniques for developing countries. Tool Publication, Leiden pg. 2-7.

Odamtten G. T. and Obodai M. (1995). Phenology of fungi and composition of five agricultural lignocelullose waste used as composts in relation to yield of Volvariella volvacea (Bull ex Fr.) Sing. In: Proceedings of Workshop on Fungal Diversity in Sub-Saharan ecosystems and their role in rural development. Dar es Salaam, Tanzania. $29^{\text {th }}$ November to $1^{\text {st }}$ December, 1995.

Purkayasthia R. P., Fas A. K. and Biswas S. (1981). Cultural practices and conditions affecting production of paddy straw mushroom. Taiwan Mushrooms 5(1):10-16.

Quimio T. H. (1986). Guide to low cost mushroom growing in the tropics. Univ. of Philippines at Los Barnos.

Quimio T. S., Chang S. T. and Royse D. J. (1990). Technical Guidelines to mushroom growing in the tropics. FAO. Rome, Italy.

Ranged C. O. and Jandaik C. L. (1977). Cultural studies on some Pleurotus spp. India J. of Mushrooms 3 (1): 9.

Sawyerr L. C. (1996). The development of the mushroom industry in Ghana. Paper presented at the Regional Workshop on Mushroom production and Mushroom germplasm collection and conservation, Harare, 23-27 September, 1996.

Sawyerr L. C. (1998). Genetic resource aspects of mushroom cultivation on small scale. In: Proceedings of the $1^{\text {st }}$ International Congress for the Characterization, Conservation, Evaluation and Utilization of Mushroom Genetic Resources for Food and Agriculture. (Ed.) Jacques E. Labarere and Umberto G. Menini. Bordeaux (France) 2000. 9-13 March, 1998.

Technical Association of the Pulp and Paper Industry (TAPPI) (1972). TAPPI Standards. Official, provisional and useful test methods. Atlanta, GA, USA.

Tschierper H. J. and Hartman K. (1977). A comparison of different mushroom growing methods. Mushroom Journal 60: 404-416.

Van Soest P. J. (1963). Use of detergents in the analysis of fibrous feeds. II. A rapid method for the determination of fiber and lignin. J. Assoc. Off. Anal. Chem. 46:829-835.

Yau C. K. and Chang S. T. (1972). Cotton waste for indoor cultivation of straw mushroom. World Crops 24: 302-303.

Cite this Article: Apetorgbor AK, Apetorgbor MM, Derkyi NSA (2015). Comparative Studies on Growth and Yield of Oil Palm Mushroom, Volvariella Volvacea (Bull. Ex. Fr.) Sing. on Different Substrates. Greener Journal of Agricultural Sciences, 5(5): 177-189, http://doi.org/10.15580/GJAS.2015.5.071115091. 